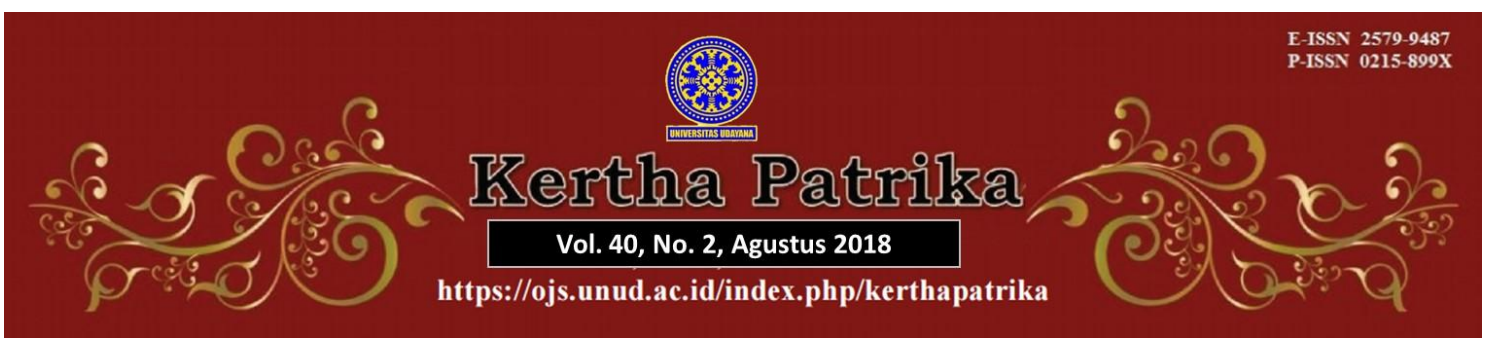

\title{
Penegakan Hukum Upaya Diversi
}

\section{Elan Jaelani ${ }^{1}$}

${ }^{1}$ Kejaksaan Negeri Probolinggo, Jawa Timur, E-mail: elanjaelani1979@gmail.com

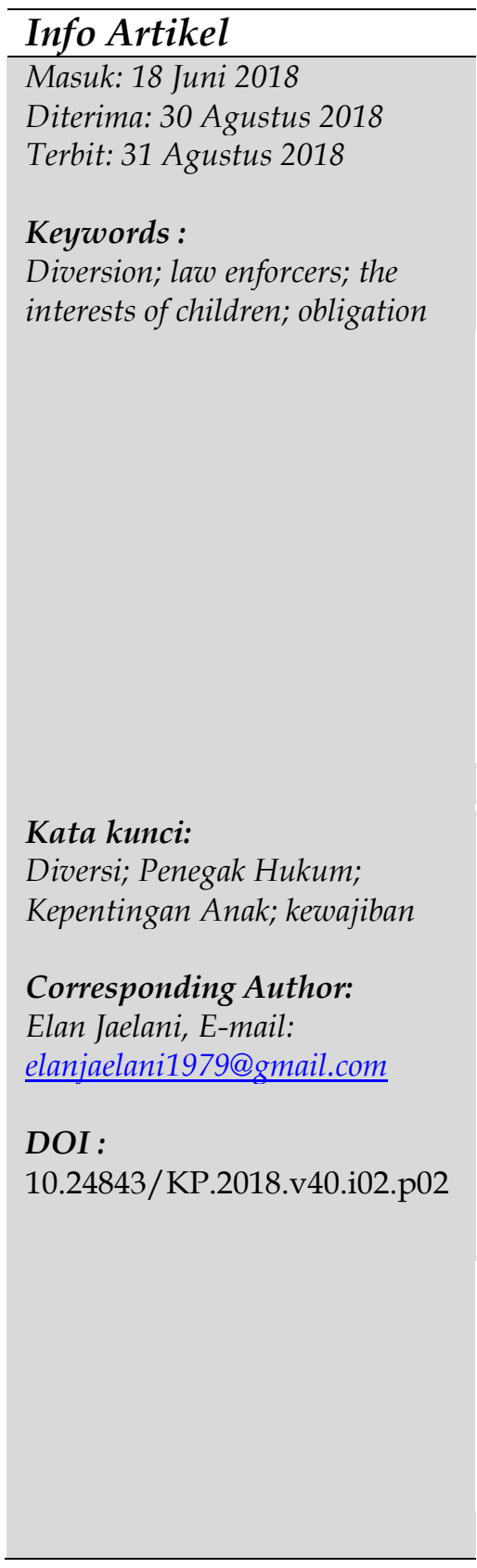

\begin{tabular}{l} 
Abstract \\
\hline Law Number 11 of 2012 concerning the Child Criminal Justice \\
System (hereinafter referred to as UUSPPA) was enacted to \\
realize a justice system that protects children's interests from the \\
negative effects of criminal justice. The form of protection of \\
children's interests is the settlement of child cases by means of \\
diversion, namely resolving cases by means of deliberation \\
outside the formal justice process. In accordance with Article 7 \\
UUSPPA, law enforcers, namely Investigators, Public \\
Prosecutors and Judges who deal with child cases that are \\
threatened with imprisonment under 7 (seven) years and non- \\
repetitive child perpetrators (recidivis), are obliged to carry out \\
diversion. This provision in practice turns out to be understood \\
differently by law enforcement. In some, cases children who do \\
not fulfill the provisions of Article 7 paragraph (2) of UUSPPA \\
and have been dealt with, children are treated differently ie one \\
law enforcer carries out diversion while other law enforcers do \\
not do so. This difference in treatment will greatly harm \\
children's interests.
\end{tabular}

Abstrak
Undang-undang Nomor 11 Tahun 2012 tentang Sistem
Peradilan Pidana Anak (selanjutnya disebut UUSPPA) dibentuk
untuk mewujudkan sistem peradilan yang melindungi
kepentingan anak dari efek negatif peradilan pidana. Bentuk
perlindungan kepentingan anak adalah penyelesaian perkara
anak dengan cara diversi yaitu menyelesaikan perkara dengan
cara musyawarah di luar proses peradilan formal. Sesuai dengan
Pasal 7 UUSPPA penegak hukum yaitu Penyidik, Penuntut
Umum dan Hakim yang menangani perkara anak yang diancam
dengan pidana penjara di bawah 7 (tujuh) tahun dan pelaku
anak bukan pengulangan (residivis), wajib untuk melaksanakan
diversi. Ketentuan ini dalam prakteknya ternyata dipahami
secara berbeda oleh penegak hukum. Dalam beberapa perkara
anak yang tidak memenuhi ketentuan Pasal 7 ayat (2) UUSPPA
dan sudah ditangani, anak diperlakukan secara berbeda yakni
satu penegak hukum melakukan diversi sedangkan penegak
hukum lainnya tidak melakukannya. Perbedaan perlakuan ini
akan sangat merugikan kepentingan anak.




\section{Pendahuluan}

Salah satu asas hukum acara pidana adalah perlakuan yang sama oleh hukum. Perlakuan yang sama oleh hukum artinya setiap pelaku tindak pidana harus mendapatkan perlakuan yang sama dari penegak hukum, pelaku tindak pidana harus diberikan hak-haknya sehingga dapat mengambil manfaat. Hak-hak Pelaku tindak pidana tidak didasarkan kepada ras, etnis, golongan, warna kulit, dan sebagainya. Termasuk anak sebagai pelaku tindak pidana mempunyai hak untuk diperlakukan sama oleh hukum.

Perlakuan yang sama oleh hukum bisa juga berarti perlakuan atau penindakan yang sama oleh penegak hukum terhadap semua pihak yang terjait dalam menangani perkara anak. Anak yang berhadapan dengan hukum, baik sebagai yang berkonflik/pelaku, korban dan saksi tindak pidana tidak boleh mendapatkan efek buruk dari berjalannya suatu sistem peradilan pidana. Undang-undang Nomor 11 Tahun 2012 tentang Sistem Peradilan Pidana Anak (selanjutnya disebut UUSPPA) menghendaki adanya suatu sistem peradilan pidana sendiri yang diharapkan dapat memberikan perlindungan terhadap anak. Hal ini dapat dilihat dari sistem penyelesaian pidana yang mengedepankan Restorative Justice, seperti perdamaian antar para pihak sebagai upaya untuk mengeluarkan anak dari sistem peradilan pidana yang diatur dalam Kitab Undang-undang Hukum Acara Pidana yang lebih mengedepankan normative justice.

Salah satu hak anak dalam UUSPPA adalah mendapatkan perlakuan dari penegak hukum untuk diupayakan diversi atas perkara yang dihadapinya. Diversi sebagai hak anak diatur dalam Pasal 7 UUSPPA yang berbunyi:

Ayat (1) "Pada tingkat penyidikan, penuntutan, dan pemeriksaan perkara Anak di pengadilan negeri wajib diupayakan Diversi."

Ayat (2) "Diversi sebagaimana dimaksud pada ayat (1) dilaksanakan dalam hal tindak pidana yang dilakukan:

a. diancam dengan pidana penjara di bawah 7 (tujuh) tahun; dan

b. bukan merupakan pengulangan tindak pidana."

Ketentuan tersebut diimplementasikan oleh penegak hukum baik Penyidik, Penuntut Umum maupun Hakim dalam menangani perkara anak, dengan cara mengupayakan diversi. Praktiknya, tidak semua penegak hukum mengupayakan diversi perkara anak, hal tersebut dapat dilihat dalam 2 (dua) contoh kasus di bawah ini :

1. Perkara anak di Pengadilan Negeri Bangli atas nama anak I Gede Aldi Alias Gede Ardiasa melakukan tindak pidana Pencurian dengan pemberatan Pasal 363 ayat (1) ke-4 dan ke-5, KUHPidana, terhadap perkara tersebut Penyidik Kepolisian Resort Bangli telah melakukan Upaya Diversi namun gagal. Selanjutnya perkara tersebut tidak dilakukan upaya diversi oleh Penuntut Umum dikarenakan tindak pidana tidak memenuhi ketentuan Pasal 7 UUSPPA, sehingga dijatuhi pidana penjara percobaan.

2. Perkara anak di Kejaksaan Negeri Amlapura atas nama anak I Komang Merta Prayoga, melakukan tindak pidana sebagaimana dimaksud Pasal 81 ayat (2) UU Nomor Nomor 35 Tahun 2015 tentang Perubahan Atas UU Nomor 23 Tahun 2002 tentang Perlindungan Anak. Terhadap perkara tersebut Penyidik Kepolisian Sektor Abang Karang Asem dan Penuntut Umum Kejaksaan Negeri Karangasem tidak 
mengupayakan diversi, kemudian Hakim Pengadilan Negeri Amlapura berhasil melaksanakan diversi.

Perlakuan yang berbeda dalam 2 (dua) contoh kasus di atas menggambarkan adanya pelaku anak yang tidak mendapatkan haknya untuk diupayakan diversi. dengan tidak mendapatkan haknya tersebut maka anak akan terkena pengaruh oleh efek negatif beracara di pengadilan, dan masa depan anak akan terganggu.

Berdasarkan uraian di atas, maka dirumuskan permasalahan yaitu, pertama : Bagaimana penegakan hukum upaya diversi yang ditentukan Pasal 7 UUSPPA di Kabupaten Bangli, dan kedua : faktor apa yang mempengaruhi penegakan hukum upaya diversi tersebut.

Tujuan penelitian ini yaitu pertama untuk mengetahui dan menganalisa penegakan hukum upaya diversi sebagaimana ditentukan dalam Pasal 7 UUSPPA dan kedua untuk menemukan pemahaman yang tepat tentang diversi sebagaimana dimaksud Pasal 7 UUSPPA, sehingga dengan pemahaman yang tepat diharapkan dapat dijadikan masukan kepada penegak hukum yang menangani perkara anak, kemudian akhirnya terwujud keseragaman dalam penegakan hukum diversi perkara anak.

Terdapat beberapa penelitian dalam bentuk jurnal yang mengangkat topik yang relatif senada dengan penelitian ini, diantaranya: 1) Jurnal yang disusun oleh Widodo (mahasiswa Fakultas Hukum Universitas Wisnuwardhana Malang), dengan Judul "Diversi dan Keadilan Restoratif Dalam Sistem Peradilan Pidana Anak di Indonesia". ${ }^{1}$ Dalam jurnal tersebut dibahas 3 (tiga) permasalahan, yaitu a) Apakah urgensi diversi dalam penanganan perkara anak? b) Bagaimana kesiapan para pihak yang terlibat dalam diversi perkara anak? c) Bagaimana model pendidikan, pembinaan dan pendampingan dan pengawasan anak yang didiversi maupun yang dijatuhi pidana?, 2) Jurnal yang disusun oleh Umi Supraptiningsih (Dosen STAIN Pamekasan), dengan Judul "Kesiapan Penegak Hukum Di Kabupaten Pamekasan Dalam Pemberlakuan UU No. 11 Tahun 2012 Tentang Sistem Peradilan Pidana Anak".2 Dalam jurnal tersebut dibahas 3 (tiga) permasalahan, yaitu: a) Bagaimana pemahaman penegak hukum di Kabupaten Pamekasan atas UU No. 11 Tahun 2012 tentang Sistem Peradilan Pidana Anak? b) Bagaimana persiapan penegak hukum di Kabupaten Pamekasan dalam pemberlakuan UU No. 11 Tahun 2012 tentang Sistem Peradilan Pidana Anak? c) Apa saja faktor pendukung dan penghambat kesiapan penegak hukum di Kabupaten Pamekasan atas pemberlakuan UU No. 11 Tahun 2012 tentang Sistem Peradilan Pidana Anak?, 3) Jurnal yang disusun oleh Ani Purwati dan Arif Samsul Alam (mahasiswa Universitas Wijaya Putra), dengan Judul "Diversi Sebagai Wujud Kebijakan Pemidanaan Dalam Sistem Peradilan Pidana Anak di Indonesia". ${ }^{3}$ Dalam jurnal tersebut dibahas 2 (dua) permasalahan tentang : a) Bagaimana pengaturan kebijakan pemidanaan keadilan restoratif terhadap perlindungan hak anak dalam sistem peradilan pidana Indonesia? b) Bagaimana implementasi diversi dalam penanggulangan tindak pidana anak? Setelah

${ }^{1}$ Widodo, W.(2015). Diversi dan Keadilan Restoratif Dalam Sistem Peradilan Pidana Anak di Indonesia, Rechtldee, 10(12)

2 Supraptiningsih, U.(2014). Kesiapan Penegak Hukum Di Kabupaten Pamekasan Dalam Pemberlakuan UU No. 11 Tahun 2012 Tentang Sistem Peradilan Pidana Anak, Nuansa, 11(1)

3 Purwati, A. \& et.al.(2015). Diversi Sebagai Wujud Kebijakan Pemidanaan Dalam Sistem Peradilan Pidana Anak di Indonesia, de Jure, Jurnal Syariah dan Hukum, 7(2) 
dilakukan pembandingan maka dari ketiga jurnal tersebut tidak ditemukan permasalahan yang sama dengan jurnal yang disusun.

\section{Metode Penelitian}

Artikel ini merupakan penelitian hukum empirik (socio-legal research) yang melihat objek penelitian yaitu hukum sebagai gejala sosial, yang memandang hukum dari luarnya saja. Hukum sebagai gejala sosial selalu berkaitan dengan segala permasalahan sosial seperti, politik, ekonomi dan budaya masyarakat. Objek penelitian adalah penegkan hukum upaya diversi yang berlokasi di Kabupaten Bangli Provinsi Bali.

Pendekatan yang digunakan adalah pendekatan Yuridis Sosiologis yaitu pendekatan sebagai norma atau kaidah hukum serta bagaimana hukum dalam pelaksanaannya (law in action) atau dengan kata lain pendekatan terhadap ketentuan perundangundangan yang berlaku efektif/tidak efektif di dalam masyarakat. Dengan pendekatan ini maka hukum dipandang sebagai gejala sosial yang terus berubah sesuai dengan kondisi masyarakatnya.

Penelitian ini bersifat deskriptif yaitu jenis penelitian yang sifatnya mendeskrifsikan atau menjelaskan peraturan perundang-undangan yang saat ini berlaku sebagai hukum positif. Penelitian deskriptif adalah penelitian yang bertujuan untuk melukiskan sesuatu hal di daerah tertentu dan pada saat tertentu. Biasanya dalam penelitian ini, peneliti sudah mendapatkan/mempunyai gambaran yang berupa data awal tentang permasalahan yang akan diteliti. ${ }^{4}$

Data yang digunakan dalam penelitian ini adalah data primer yang diperoleh dengan cara wawancara dan observasi, 5 dan data sekunder yang diperoleh dengan cara menelusuri, mengumpulkan, mengklasifikasi dan mengkaji bahan-bahan hukum primair sekunder dan tersier. Adapun analisa yang digunakan adalah analisis kualitatif yaitu analisis yang menjelaskan secara sistematis hal-hal yang diperoleh selama penelitian, sehingga dapat diperoleh gambaran tentang objek penelitian.

Cara yang digunakan untuk menentukan sampel adalah yaitu dengan cara Non Probability sampling yaitu penentuan sampel sesuai dengan kehendak dari penulis karena dianggap relevan dengan ciri-ciri yang diinginkan. Teknik Non Probability Sampling terdiri dari beberapa bentuk, yaitu Quota Sampling, Accidental Sampling, Purposive sampling, Snowball Sampling. Adapun bentuk Non Probability Sampling yang dipergunakan di dalam penelitian ini adalah Purposive sampling, yaitu berupa penarikan sampel dilakukan berdasarkan tujuan tertentu, yaitu sampel dipilih dan ditentukan sendiri oleh peneliti.

\footnotetext{
${ }^{4}$ Suratman, PD.(2014). Metode Penelitian Hukum, Bandung: CV. Alfabeta, h. 47.

${ }^{5}$ Wawancara dilakukan terhadap Penyidik, Penuntut Umum dan Hakim, sedangkan observasi dilaksanakan terhadap pelaksanaan diversi oleh Penuntut Umum di Kejaksaan Negeri Bangli.
} 


\section{Hasil dan Pembahasan}

Ada asumsi dalam sistem peradilan pidana anak dengan paradigma restoratif, bahwa di dalam mencapai tujuan penjatuhan sanksi, maka diikutsertakan korban untuk berhak aktif terlibat dalam proses peradilan. indikator pencapaian tujuan penjatuhan sanksi tercapai dengan dilihat pada apakah korban telah direstorasi, kepuasan korban, besar ganti rugi, kesadaran pelaaku atas perbuatannya, jumlah kesepakatan perbaikan yang dibuat, kualitas pelayanan kerja dan keseluruhan proses yang terjadi. Bentukbentuk sanksi yaitu restitusi, mediasi pelaku korban, pelayanan korban, restorasi masyarakat, pelayanan langsung pada korban atau denda restoratif. ${ }^{6}$

Keadilan restoratif sebagai setiap tindakan untuk menegakkan keadilan dengan memperbaiki kerusakan yang ditimbulkan akibat dari suatu tindak pidana. Keadilan restoratif mendasarkan jenis pemidanaan berupa pelayanan masyarakat, ganti rugi, dan bentuk lain selain dari hukuman penjara, dengan membiarkan terpidana untuk tetap aktif dalam masyarakat. ${ }^{7}$

Pasal 1 angka 6 UUSPPA menentukan keadilan restoratif sebagai suatu penyelesaian pekara tindak pidana anak dengan menitikberatkan pada pengakuan pelaku dengan membebankan kewajiban untuk bertanggung jawab guna memulihkan keadaan yang terganggu. Keadilan restoratif dilakukan dengan cara melibatkan pelaku, korban, keluarga pelaku/korban, dan pihak lain yang berkaitan, yang bertujuan untuk bersama-sama mencari penyelesaian yang sesuai dengan kehendak para pihak, dengan menekankan pemulihan kembali kepada keadaan semula dan bukan pembalasan.

Bentuk perlindungan hukum yang diberikan oleh UUSPPA terhadap anak yang berkonflik dengan hukum mulai dari tahap penyelidikan hingga akhirnya pelaksanaan putusan di lembaga pemasyarakatan anak telah menunjukkan adanya perlindungan yang khusus terhadap hak-hak anak. Hal ini terlihat dengan diwajibkannya Pejabat Khusus Anak untuk menangani perkara anak dalam setiap tahap pemeriksaan dan juga penahanan terhadap anak hanya akan dilakukan sebagai ultimum remedium serta selama penahanan kebutuhan anak harus tetap dipenuhi. ${ }^{8}$

Pendekatan keadilan restoratif wajib dilakukan dalam penyelesaian perkara anak sebagaimana ditentukan Pasal 5 ayat (1) UUSPPA. Hal ini guna menjamin perlindungan atas kepentingan anak, sehingga anak terhindar dari segala efek buruk pemidanaan yang mengedepankan keadilan distributif.

Keadilan restoratif sebagai bentuk penyelesaian dalam perkara anak kemudian diwujudkan dalam diversi. Menurut Setya Wahyudi diversi adalah pengalihan proses formal pemeriksaan perkara anak kepada proses informal dalam bentuk program-

\footnotetext{
${ }^{6}$ Djamil, M.N. (2013). Anak Bukan untuk Dihukum, Jakarta: Sinar Grafika (cetakan kedua), h. 4647.

7 Kaligis, O.C. (2006). Pelindungan Hukum Atas Hak Asasi Tersangka, Terdakwa, dan Terpidana, Jakarta: Alumni, h. 125.

8 Sibarani, E. (2013). Perlindungan Hukum terhadap Anak yang Berkonflik dengan Hukum menurut Undang-Undang No. 11 Tahun 2012 Tentang Sistem Peradilan Pidana Anak, Jurnal Mahupiki 2(1)
} 
program diversi, jika memenuhi syarat-syarat tertentu. ${ }^{9}$ Sehingga untuk sementara dapat dikemukakan, bahwa pada hakikatnya diversi itu adalah suatu pengalihan proses penyelesaian perkara anak dari proses hukum acara yang berlaku umum (Sistem Peradilan Pidana atau SPP), ke proses penyelesaian perkara anak yang menggunakan hukum acara khusus untuk menyelesaikan perkara pidana anak. ${ }^{10}$

Pasal 1 UUSPPA menentukan bahwa diversi merupakan perwujudan dari pendekatan keadilan restoratif. Diversi merupakan cara penyelesaian di luar proses peradilan pidana yang diwujudkan dengan cara musyawarah. Maksud dan tujuan dari diversi adalah menghindarkan anak dari prosedur resmi beracara di pengadilan dan mengurangi kemungkinan terjadinya bentuk residivisme di masa mendatang. Hal tersebut sebagaimana ditentukan dalam Pasal 6 UUSPPA menyatakan tujuan diversi adalah untuk mewujudkan perdamaian antara korban dan pelaku anak, dilakukan diluar proses peradilan, anak tidak dirampas kemerdekaannya, menciptakan partisipasi masyarakat dan menanamkan rasa tanggung jawab pada pelaku anak.

Dalam melaksanakan diversi hal yang harus dipahami oleh penegak hukum adalah anak sebagai pelaku tinda pidana akibat dari kondisi lingkungan dan perkembangan teknologi. Tindak pidana yang dilakukan anak baik langsung maupun tidak langsung merupakan suatu akibat dari perbuatan dan tindakan yang dilakukan orang dewasa dalam bersinggungan dengan anak atau merupakan sebagai bagian dalam proses interaksi anak dengan lingkungannya, dimana anak belum mampu menyikapinya. Paradigma ini harus ditanamkan bagi masyarakat dan apratur penegak hukum dalam menghadapi anak yang diduga melakukan suatu tindak pidana. ${ }^{11}$

Kewajiban melaksanakan diversi dimulai sejak Penyidikan oleh Peyidik, kalau tidak berhasil kemudian dilakukan ditingkat penuntutan oleh Penuntut Umum, kalau tidak berhasil juga maka dilakukan di persidangan. Pasal 7 UUSPPA mengandung kewajiban bagi Penyidik, Penuntut Umum dan Hakim melakukan diversi. Oleh karena diversi adalah kewajiban bagi Penyidik, Penuntut Umum dan Hakim, maka diversi wajib dilakukan terhadap perkara anak yang ditangani, sehingga apabila tidak dilaksanakan maka aparat penegak hukum tersebut dapat diminta pertanggungjawaban.

Pelaksanaan diversi oleh penegak hukum pada pokoknya dapat dibagi ke dalam tahapan sebagai berikut:

1. Upaya diversi;

2. Musyawarah diversi;

3. Kesepakatan diversi;

4. Pelaksanaan kesepakatan diversi;

5. Pengawasan pelaksanaan diversi;

6. Penghentian perkara.

\footnotetext{
${ }^{9}$ Wahyudi, S. (2011). Implementasi Ide Diversi, Dalam Pembaharuan Sistem Pidana Anak di Indonesia, Yogyakarta: Genta Publishing, h. 58.

10 Sinaga, D. (2017). Penegakan Hukum Dengan Pendekatan Diversi (Perspektif Teori Keadilan bermartabat), Yogyakarta: Nusa Media, h. 28.

${ }_{11}$ Djamil, M.N. (2013). Anak Bukan untuk Dihukum, Jakarta: Sinar Grafika (cetakan kedua), h.54.
} 
Berdasarkan Pasal 7 UUSPPA tersebut yang diwajibkan adalah upaya diversi. Upaya diversi yang dimaksud adalah tindakan Penyidik atau Penuntut Umum atau Hakim untuk:

1. Memberitahu dan menawarkan kepada anak dan/atau orang tua/wali, serta korban atau anak dan/atau orang tua/wali untuk menyelesaikan perkara dengan cara diversi sebagaimana ditentukan dalam Pasal 83 Peraturan Pemerintah Nomor 65 Tahun 2015 tentang Pedoman Pelaksanaan Diversi dan Penanganan Anak Yang Belum Berumur 12 (dua belas) Tahun;

2. Memanggil para pihak tentang upaya diversi;

3. Membuat berita acara upaya diversi;

4. Menentukan tanggal musyawarah apabila para pihak sepakat melakukan diversi sebagaimana ditentukan dalam Pasal 83 Peraturan Pemerintah Nomor 65 Tahun 2015 tentang Pedoman Pelaksanaan Diversi dan Penanganan Anak Yang Belum Berumur 12 (dua belas) tahun;

Soerjono Soekanto mengatakan penegakan hukum adalah kegiatan menyerasikan hubungan nilai-nilai yang terjabarkan di dalam kaidah-kaidah yang mantap dan mengejawantah dan sikap tindak sebagai rangkaian penjabaran nilai tahap akhir, untuk menciptakan, memelihara dan mempertahankan perdamaian dan pergaulan hidup. ${ }^{12}$ Satjipto Rahardjo mengatakan penegakan hukum merupakan suatu usaha untuk mewujudkan ide-ide tentang keadilan, kepastian hukum dan kemanfaatan sosial menjadi kenyataan. Proses perwujudan ide-ide itulah yang merupakan hakikat dari penegakan hukum. ${ }^{13}$

Tindakan penegak hukum dalam rangka penegakan hukum agar berkesuaian dengan nilai yang terkandung dalam norma pengaruhi oleh faktor-faktor non hukumya. Menurut Soerjono Soekanto bahwa masalah pokok penegakan hukum sebenarnya terletak pada faktor-faktor yang mempengaruhinya. Faktor-faktor tersebut mempunyai arti yang netral, sehingga dampak positif atau negatifnya terletak pada isi faktor-faktor tersebut. faktor-faktor tersebut adalah sebagai berikut:

1. Faktor hukumnya sendiri, yang di dalam tulisan ini akan dibatasi pada undangundang saja..

2. Faktor penegak hukum, yakni pihak-pihak yang membentuk maupun menerapkan hukum.

3. Faktor sarana atau fasilitas yang mendukung penegakan hukum.

4. Faktor masyarakat, yakni lingkungan di mana hukum tersebut berlaku atau diterapkan.

5. Faktor kebudayaan, yakni sebagai hasil karya, cipta, dan rasa yang didasarkan pada karsa manusia di dalam pergaulan hidup. ${ }^{14}$

Tindakan penegak hukum sebagaimana disebutkan di atas merupakan apa yang seharusnya dilakukan penegak hukum dalam praktik penegakan hukum perkara anak. Berdasarkan hasil wawancara, observasi dan penelitian bahan hukum berupa berkas

${ }^{12}$ Soekanto, S. (1983). Faktor-Faktor yang Mempengaruhi Penegakkan Hukum, Jakarta: Raja Grafindo, h. 7.

${ }^{13}$ Raharjo, S (2009). Penegakan Hukum Sebagai Tinjauan Sosiologis, Yogyakarta: Genta Publishing, h. 25.

14 Op. Cit, h. 8. 
perkara ditemukan ketidakserasian antara tindakan penegak hukum nyata dengan tindakan yang seharusnya, yaitu terdapat penanganan yang tidak seragam di kalangan penegak hukum yang mempunyai kewajiban melakukan diversi dalam penanganan perkara anak. Hal tersebut terjadi baik antara Penyidik dengan Penuntut Umum atau Penyidik dengan Hakim atau Penuntut Umum dengan Hakim, ataupun diantara sesama penegak hukum yang sederajat, Penyidik dengan Penyidik, Penuntut Umum dengan Penuntut Umum.

Setelah dilakukan penelaahan terhadap hasil wawancara dengan Penuntut Umum, observasi langsung dan penelitian Berkas Perkara, didapatkan hal sebagai berikut, yakni dalam hal penegakan hukum Pasal 7 UUSPPA ternyata terdapat faktor yang menjadi hambatan dalam penegakannya, faktor tersebut terdapat dalam hal antara lain:

1. Substansi hukumnya, yaitu terdapat peraturan yang bertentangan dengan Pasal 7 UUSPPA, yakni Pasal 3 Peraturan Mahkamah Agung (PERMA) Nomor 4 tahun 2014 tentang Pedoman Pelaksanaan Diversi Dalam Sistem Peradilan Pidana Anak yang menyebutkan bahwa "Hakim Anak wajib mengupayakan diversi dalam hal anak didakwa melakukan tindak pidana yang diancam dengan pidana penjara di bawah 7 tahun dan didakwa pula dengan tindak pidana yang diancam dengan pidana penjara 7 tahun atau lebih dalam bentuk surat dakwaan subsidiaritas, alternatif, kumulatif maupun kombinasi.

Pasal 3 PERMA tersebut secara vertikal telah bertentangan dengan Pasal 3 Peraturan Pemerintah (PP) Nomor 65 Tahun 2015 Tentang Pedoman Pelaksanaan Diversi Dan Penanganan Anak Yang Belum Berumur 12 (dua) belas tahun. Pasal 3 PERMA tersebut dipedomani oleh Hakim dalam pelaskanaan diversi, dan akan menimbulkan cara penegakan hukum Pasal 7 yang berbeda, yaitu untuk tindak pidana yang diancam dengan pidana di atas 7 (tujuh) tahun dimungkinkan diupayakan diversi oleh Hakim, meskipun hal tersebut dibatasi dengan bentuk dakwaan dari Penuntut Umum yang tidak tunggal.

PERMA tersebut berlaku mengikat untuk internal lingkungan Mahkamah Agung termasuk peradilan pidana anak yang berada di lingkungan peradilan umum, akan tetapi tidak berlaku bagi Penyidik dan Penuntut Umum. sehingga Penyidik dan Penuntut Umum tidak akan mengikuti PERMA. Dengan kondisi tersebut PERMA itu akan menggangu penegakan hukum upaya diversi Pasal 7 UUSPPA. Lebih jauh lagi yang paling dirugikan adalah kepentingan anak.

2. Penegak hukumnya sendiri, yaitu pengetahuan dan pemahaman hukum dari penegak hukum terhadap Pasal 7 UUSPPA yang berbeda-beda antar satu penegak hukum dengan penegak hukum lainnya. Pengetahuan dan pemahaman tersebut yaitu:

a. Menurut sebagian penegak hukum upaya diversi sebagaimana dimaksud Pasal 7 ayat (1) UUSPPA dimaknai bahwa tindak pidana yang memenuhi ketentuan Pasal 7 tersebut wajib diupayakan diversi. Oleh karena tindak pidana yang dimaksud wajib diupayakan diversi, maka tindak pidana anak yang tidak memenuhi ketentuan Pasal 7 dimaknai "tidak wajib diupayakan diversi atau dapat saja diupayakan diversi", tergantung kemauan dari penegak hukumnya, dalam hal ini upaya diversi dilakukan demi kepentingan anak. 
b. Menurut sebagian penegak hukum diversi hanya bisa dilakukan terhadap perkara anak yang memenuhi ketentuan Pasal 7 UUSPPA, sehingga perkara anak yang tidak memenuhi ketentuan Pasal 7 UUSPPA tidak dapat/tidak bisa/tidak bisa diupayakan diversi.

Perbedaan pemahaman tersebut merupakan faktor yang menjadi hambatan dalam penegakan hukum, khususnya faktor penegak hukumnya. Penegakan hukum yang tidak sama yang dikarenakan pemahaman yang berbeda akan merugiakan kepentingan anak yaitu segala keputusan yang diambil oleh penegak hukum harus selalu mempertimbangkan kelangsungan hidup dan tumbuh kembang anak.

Berdasarkan hasil penelitian oleh Slamet Rahardjo, dkk disimpulkan bahwa pelaksanaan diversi oleh hakim Pengadilan Negeri Pontianak dilakukan tidak berdasarkan pada peraturan perundang-undangan khususnya UUSPPA, karena masih ada perkara tindak pidana anak yang dakwaannya diatas 7 (tujuh) tahun dilaksanakan penyelesaiannya dengan cara diversi. Hal tersebut dapat terlihat pada Perkara Nomor. 02/Pidsus-Anak/2014/PN.PTK dan Perkara Nomor. 03/Pidsus-Anak/2014/PN.PTK dimana perkaranya adalah pencurian dalam keadaan yang memberatkan dengan dakwaan tunggal melanggar Pasal 363 ayat (1) ke-4, selain kedua kasus tersebut diatas masih ada kasus lain yang penulis ambil dari Pengadilan Negeri Mempawah yaitu perkara asusila atas nama anak ABU ZAKI AKHMAD, didakwa oleh Penuntut Umum dengan dakwaan tunggal melanggar pasal 82 Undang-undang RI Nomor 35 tahun 2014 tentang Perubahan atas Undang-undang RI No.23 tahun 2002 Tentang Perlindungan Anak, pada perkara tersebut Hakim Anak pada Pengadilan Negeri Mempawah juga melakukan diversi padahal sudah jelas menurut UU No.11 Tahun 2012 perkara tersebut tidak dapat dilakukan diversi, selain itu Hakim Anak melaksanakan diversi tanpa mengacu kepada Perma No.4 Tahun 2014 Tentang Pedoman Pelaksanaan Diversi Dalam Sistem Peradilan Pidana Anak. Bahwa faktor penyebab masih terjadi ketidak samaan dalam pelaksanaan diversi oleh hakim Pengadilan Negeri Pontianak terhadap satu kasus dengan kasus anak bermasalah dengan hukum karena pandangan hakim terhadap pelaku kejahatan anak yang berbeda-beda adalah dikarenakan beberapa faktor yaitu berkaitan dengan masalah falsafah pemidanaan, pedoman pemidanaan masalah patokan pidana,dan faktor yang bersumber dari diri Hakim sendiri sehingga penerapan diversi menjadi berbeda antara hakim yang satu dengan hakim yang lainnya di Pengadilan Negeri Pontianak. ${ }^{15}$

Berdasarkan hasil penelitian yang dilakukan oleh Marulak Pardede disimpulkan bahwa Kebijakan penyuluhan hukum/sosialisasi yang dilaksanakan oleh pemerintah (Kemenkumham cq. BPHN) dalam rangka pelaksanaan Sistem Peradilan Pidana Anak berdasarkan UUSPPA, agar Undang Undang ini dapat terselenggara dengan baik, sejak diundangkannya undang undang ini, tidak berjalan sebagaimana mestinya, karena pada umumnya kalangan masyarakat, aparat penegak hukum (hakim, polisi dan jaksa), belum sepenuhnya mengetahui akan keberadaan Undang-undang ini. Kalangan masyarakat pada umumnya, masih dominan menyelesaikan perkara anak-

15 Rahardjo, S. \& et. al. "Diversi Dalam Sistem Peradilan Pidana Anak Berdasarkan UU NOMOR 11 TAHUN 2012 Di Kota Pontianak (STUDI KASUS DI PENGADILAN NEGERI PONTIANAK). Jurnal NESTOR Magister Hukum 3(3) 
anak, dengan sistem yang lama, anak yang bersalah harus dipenjara (dikurung), tidak dengan diversi sebagaimana dimaksudkan undang-undang ini. ${ }^{16}$

Hal tersebut tentunya harus segera dilakukan upaya untuk mengatasinya, seperti meningkatkan fungsi koordinasi antar sesama penegaak hukum serta melakukan sosialisasi UUSPPA kepada penegak hukum. Saran pertemuan Mahkamah Agung, Kejaksaan dan Kepolisian (selanjutnya disebut MAHKEJAPOL) baik di pusat maupun di daerah dapat dijadikan sarana untuk menyamakan pemahaman antar sesame penegak hukum dalam penanganan perkara anak.

Guna membahas perbedaan pemahaman tersebut, akan diuraikan beberapa pendapat ahli tentang makna dari Pasal 7 UUSPPA:

1. Pendapat M Nasir Djamil sebagai berikut diversi wajib diupayakan pada tingkat penyidikan, penuntutan dan pemeriksaan anak di Pengadilan Negeri. Kata "wajib diupayakan" mengandung makna bahwa penegak hukum anak dari Penyidik, Penuntut Umum dan juga Hakim diwajibkan untuk melakukan upaya agar proses diversi bisa dilaksanakan. Hal ini lah yang membuat perdebatan dalam panja RUU SPPA, bahwa bagi penegak hukum anak apabila tidak melakukan upaya diversi haruslah diberi sanksi. ${ }^{17}$

2. Pendapat R. Wiyono sebagai berikut :

"dengan demikian, perkara anak yang tidak wajib diupayakan diversi adalah perkara anak yang tindak pidananya dilakukan :

1.Diancam dengan pidana penjara di atas 7 (tujuh) tahun, atau

2.Merupakan pengulangan tindak pidana.

Pengertian "tidak wajib diupayakan diversi" tersebut pengertiannya adalah tidak bersifat imperative atau fakultatif. Artinya perkara anak yang tindak pidananya diancam pidana penjara di atas 7 (tujuh) tahun atau merupakan pengulangan tindak pidana, dapat saja diupayakan diversi". ${ }^{18}$

UUSPPA mengamanatkan adanya suatu proses perubahan paradigma berfikir yang mengutamakan kepentingan terbaik bagi anak dan perlindungan terhadap hak anak. ${ }^{19}$ Di samping itu juga aparat penegak hukum perlu memperhatikan tujuan dari diversi, sebagaimana ditentukan dalam berdasarkan Pasal 6 UUSPPA menyatakan tujuan diversi adalah untuk mewujudkan perdamaian antara korban dan pelaku anak, dilakukan di luar proses peradilan, anak tidak dirampas kemerdekaannya, menciptakan partisipasi masyarakat dan menanamkan rasa tanggung jawab pada pelaku anak. Dengan memahami tujuan diversi tersebut maka seharusnya aparat penegak hukum lebih mengutamakan diversi sebagai cara pertama/yang didahulukan sebelum dengan acara peradilan pidana.

\footnotetext{
16Pardede, M. (2017). Aspek Hukum kebijakan Penyuluhan Hukum Dalam Rangka Pelaksanaan Sistem Peradilan Pidana Anak, Jurnal Penelitian Hukum De Jure 17(1), h. 13-28.

${ }^{17}$ M Nasir Djamil, 2013, Anak Bukan untuk Dihukum, Sinar Grafika (cetakan kedua), Jakarta, h.138.

${ }^{18}$ R. Wiyono, (2016), Sistem Peradilan Pidana Anak Di Indonesia, Jakarta: Sinar Grafika, h.51.

19 Ariani, N. V. (2014). Implementasi Undang-Undang Nomor 11 Tahun 2012 Tentang Sistem Peradilan Pidana Anak Dalam Upaya Melindungi Kepentingan Anak, Jurnal Media Hukum, 21(1), h. 16.
} 
Tujuan-tujuan sistem peradilan pidana tersebut, tentunya sedikit banyak berlaku bagi tujuan penyelenggaraan sistem peradilan pidana anak yaitu, tujuan jangka pendek sistem peradilan pidana anak adalah resosialisasi atau pembinaan untuk mempersiapkan kembali kepada masyarakat bagi pelaku anak. Tujuan jangka menengah sistem peradilan pidana anak adalah mencegah pelaku anak tersebut melakukan kejahatan lebih lanjut dan jangka panjang untuk kesejahteraan pelaku anak dan masyarakat pada umumnya. ${ }^{20}$

Diversi pada hakikatnya juga mempunyai tujuan agar anak terhindar dari dampak negatif pemidanaan. Diversi juga mempunyai esensi tetap menjamin anak tumbuh dan berkembang baik secara fisik maupun secara mental. Dengan demikian dapat dikatakan bahwa pada dasarnya diversi mempunyai relevansi dengan tujuan pemidanaan anak. UUSPPA lebih mengedepankan penyelesaian anak yang berkonflik dengan hukum penanganan penyelesaian secara keadilan restoratif yaitu penyelesaian perkara dengan melibatkan pelaku, korban, keluarga pelaku/korban, dan pihak lain yang terkait untuk bersama-sama mencari penyelesaian yang adil dengan menekankan pemulihan kembali pada keadaan semula. ${ }^{21}$

Menurut Setya Wahyudi Sistem peradilan pidana anak adalah sistem penegakan hukum pidana anak yang dilaksanakan secara terpadu oleh 4 (empat) sub sistem kekuasaan, yaitu kekuasaan penyidikan, kekuasaan penuntutan, kekuasaan mengadili/menjatuhkan pidana, dan kekuasaan eksekusi/pelaksanaan pidana, berdasarkan hukum pidana materiil anak, hukum pidana formal anak dan hukum pelaksanaan pidana anak. Dan aktivitas dalam penegakan hukum anak ini lebih menekankan pada kepentingan perlindungan anak dan tujuan kesejahteraan anak. ${ }^{22}$

Berdasarkan uraian di atas maka dapat disimpulkan sebagai berikut:

1. Diversi tujuan utamanya adalah perlindungan kepentingan dan kesejahteraan anak;

2. Upaya diversi terhadap perkara anak yang tidak memenuhi ketentuan Pasal 7 ayat (2) UUSPPA diserahkan kepada kehendak dari penegak hukum sesuai kewenangan diskresi demi mewujudkan perlindungan atas kepentingan anak dan kesejahteraan anak;

3. Upaya diversi tetap memperhatikan keinginan korban/anak korban;

Maka dari pada itu, apabila penegak hukum yang melakukan upaya diversi terhadap perkara anak yang tidak memenuhi ketentuan Pasal 7 UUSPPA maka sama sekali tidak bertentangan dengan UUSPPA, asalkan hal tersebut benar-benar untuk kepentingan anak dan kesejahteraan anak, dengan tetap memperhatikan keinginan korban/anak korban dan/atau orang tua/wali. Apabila diversi berhasil justru tujuan menjauhkan anak dari efek buruk proses peradilan pidana formal bisa tercapai dan kepentingan anak terlindungi.

20 Wahyudi, S. (2011). Implementasi Ide Diversi, Dalam Pembaharuan Sistem Pidana Anak di Indonesia, Yogyakarta: Genta Publishing, h. 38

${ }^{21}$ Wati, E.R. (2017). Penanganan Anak yang Berkonflik dengan Hukum. Justitia Jurnal Hukum, $1(2)$

22 Op.cit. h. 37. 


\section{Kesimpulan}

Berdasarkan pembahasan di atas maka dapat ditarik kesimpulan sebagai berikut:

1. Terdapat ketidakseragaman tindakan dari penegak hukum dalam upaya diversi sebagaimana dimaksud dengan Pasal 7 UUSPPA.

2. Perbedaan penegakan hukum tersebut disebabkan oleh:

a. Faktor substansi hukumnya, yaitu :

Terdapat peraturan yang bertentangan dengan Pasal 7 UUSPPA, yakni Pasal 3 Peraturan Mahkamah Agung (PERMA) Nomor 4 tahun 2014 tentang Pedoman Pelaksanaan Diversi Dalam Sistem Peradilan Pidana Anak yang menyebutkan bahwa "Hakim Anak wajib mengupayakan diversi dalam hal anak didakwa melakukan tindak pidana yang diancam dengan pidana penjara di bawah 7 tahun dan didakwa pula dengan tindak pidana yang diancam dengan pidana penjara 7 tahun atau lebih dalam bentuk surat dakwaansubsidiaritas, alternatif, kumulatif maupun kombinasi.

b. Faktor penegak hukumnya, yaitu:

1. Terdapat pandangan bahwa upaya diversi wajib dilakukan apabila memenuhi ketentuan Pasal 7 ayat (2) UUSPPA, sehingga apabila tidak diupayakan diversi maka penegak hukum akan dikenakan sanksi sebagaimana dimaksud Pasal 96 UUSPPA (pada tahun 2013 sudah dicabut dan dinyatakan tidak berlaku berdasarkan Putusan Mahkamah Konstitusi). Menurut pandangan ini perkara anak yang tidak memenuhi ketentuan Pasal 7 ayat (2) UUSPPA merupakan diskresi penegak hukum, artinya apabila penegak hukum menghendaki maka diupayakan diversi, dan sebaliknya. Upaya diversi tersebut semata-mata karena untuk perlindungan anak dan pemenuhan kepentingan anak.

2. Terdapat juga pandangan bahwa Pasal 7 UUSPPA adalah batasan bagi penegak hukum dalam mengupayakan diversi. Perkara anak yang memenuhi ketentuan Pasal 7 ayat (2) UUSPPA bisa dilakukan diversi, sedangkan yang tidak memenuhi ketentuan tersebut tidak bisa diversi. Menurut pandangan ini sanksi karena tidak mengupayakan diversi tidak penting, dan apabila penegak hukum melakukan diversi terhadap perkara anak yang tidak memenuhi ketentuan Pasal 7 ayat (2) UUSPPA maka penegakannya salah, dan hakim harus menolak permohonan penetapan diversinya.

\section{Daftar Pustaka}

Buku

Djamil, M.N. (2013). Anak Bukan untuk Dihukum, Jakarta: Sinar Grafika (cetakan kedua)

Kaligis, O.C. (2006). Pelindungan Hukum Atas Hak Asasi Tersangka, Terdakwa, dan Terpidana, Jakarta: Alumni

M Nasir Djamil, 2013, Anak Bukan untuk Dihukum, Sinar Grafika (cetakan kedua), Jakarta

Raharjo, S (2009). Penegakan Hukum Sebagai Tinjauan Sosiologis, Yogyakarta: Genta Publishing

Sinaga, D. (2017). Penegakan Hukum Dengan Pendekatan Diversi (Perspektif Teori Keadilan bermartabat), Yogyakarta: Nusa Media 
Soekanto, S. (1983). Faktor-Faktor yang Mempengaruhi Penegakkan Hukum, Jakarta: Raja Grafindo

Suratman, PD.(2014). Metode Penelitian Hukum, Bandung: CV. Alfabeta

Wahyudi, S. (2011). Implementasi Ide Diversi, Dalam Pembaharuan Sistem Pidana Anak di Indonesia, Yogyakarta: Genta Publishing

Wiyono, 2016, Sistem Peradilan Pidana Anak Di Indonesia, Jakarta: Sinar Grafika

Jurnal

Ariani, N. V. (2014). Implementasi Undang-Undang Nomor 11 Tahun 2012 Tentang Sistem Peradilan Pidana Anak Dalam Upaya Melindungi Kepentingan Anak, Jurnal Media Hukum, 21(1)

Purwati, A. \& et.al.(2015). Diversi Sebagai Wujud Kebijakan Pemidanaan Dalam Sistem Peradilan Pidana Anak di Indonesia, de Jure, Jurnal Syariah Dan Hukum, 7(2)

Rahardjo, S. \& et. al. "Diversi Dalam Sistem Peradilan Pidana Anak Berdasarkan UU NOMOR 11 TAHUN 2012 Di Kota Pontianak (STUDI KASUS DI PENGADILAN NEGERI PONTIANAK). Jurnal NESTOR Magister Hukum 3(3)

Sibarani, E. (2013). Perlindungan Hukum terhadap Anak yang Berkonflik dengan Hukum menurut Undang-Undang No. 11 Tahun 2012 Tentang Sistem Peradilan Pidana Anak, Jurnal Mahupiki 2(1)

Supraptiningsih, U.(2014). Kesiapan Penegak Hukum Di Kabupaten Pamekasan Dalam Pemberlakuan UU No. 11 Tahun 2012 Tentang Sistem Peradilan Pidana Anak, Nuansa, 11(1)

Wati, E.R. (2017). Penanganan Anak yang Berkonflik dengan Hukum. Justitia Jurnal Hukum, 1(2)

Widodo, W.(2015). Diversi dan Keadilan Restoratif Dalam Sistem Peradilan Pidana Anak di Indonesia, Rechtldee, 10(12)

\section{Peraturan Perundang-undangan}

UU Nomor 11 Tahun 2012 Tentang Sistem Peradilan Pidana Anak, Lembaran Negara Republik Indonesia Tahun 2012 Nomor 153, Tambahan Lembaran Negara Republik Indonesia Nomor 5332.

Peraturan Pemerintah Nomor 65 tahun 2015 tentang Pedoman Pelaksanaan Diversi dan Penanganan Anak Yang Belum Berumur 12 (dua belas) Tahun, Lembaran Negara Republik Indonesia Tahun 2015 Nomor 194, Tambahan Lembaran Negara Republik Indonesia Nomor 5732. 
Peraturan Jaksa Agung Republik Indonesia Nomor : PER-006/A/JA/04/2015 Tanggal 15 April 2015 Tentang Pelaksanaan Diversi Pada Tingkat Penuntutan dan lampirannya, Berita Negara Republik Indonesia Tahun 2015 Nomor 621.

Peraturan Mahkamah Agung Nomor 4 tahun 2014 Pedoman Pelaksanaan Diversi Dalam Sistem Peradilan Pidana Anak, Berita Negara Republik Indonesia Tahun 2014 Nomor 1052. 